\title{
Közlemény
}

\section{Megalakult a Gazsó Ferenc Társadalomtudományi Társaság (GFTT)}

\author{
https://doi.org/10.51624/SzocSzemle.2019.1.7
}

Gazsó Ferenc tisztelői és barátai kezdeményezésére 2018. december 12-én megalakult az egyesületi formában múködő Gazsó Ferenc Társadalomtudományi Társaság, amelynek célja a névadó szellemi örökségének gondozása. Ennek keretében olyan közéleti ügyeket, kutatási kérdéseket igyekszünk napirenden tartani, amelyek

- a közoktatás társadalmi összefüggéseire és az oktatáspolitikára,

- a magyar társadalom generációs újratermelődésének alakulására és az ifúságkutatásra,

- az életesélyek társadalmi egyenlőtlenségeire vonatkoznak.

A fenti megfontolások szem előtt tartásával a Társaság a következő közvetlen célokat tűzi ki maga elé:

- Konferenciasorozatot szervez, amelyben előadások hangzanak el és eszmecserék szerveződnek a Gazsó Ferenc emlékének szentelt és a Társaság által fontosnak tartott fenti témákban.

- Gazsó Ferenc Emlékdijjat alapít, amelyet egy erre a célra választott kuratórium - kétévente - ítél oda két fiatal magyar kutatónak, akik a fenti témák valamelyikében komoly, rangos kutatómunkát végeznek.

Az iskolaügy, az ifúság, valamint a társadalmi egyenlőtlenségek témaköreiben szervezett konferenciák előadásait kötetekben tervezzük közreadni. Előkészületben van a 2019-ben - „Iskola, társadalom, politika” címmel - megjelenő kötet, amely Gazsó Ferenc e témakörben korábban publikált, illetve eddig még nem közölt írásait, valamint más szerzőknek a témához kapcsolódó tanulmányait adja közre.

A Társaság abban a szellemben müködik, amelyet Gazsó Ferenc fontosnak tartott: minél kevésbé formális, lényegre törő, egyszerű működésre, baráti, empatikus légkörre, nyitott szellemi közeg megteremtésére törekszik. A Társaság múködését értékelkötelezett szakszerǔség és a társadalmi problémák iránti nyitottság jellemzi, amelyet elvár az általa támogatott személyektől is. Az alakuló közgyúlés Dr. Bihari Mihályt választotta a Társaság elnökévé. 
A Társaság nyitott. Tagjává válhat mindenki, aki a fentiekben megfogalmazott célokkal, értékekkel és eszközökkel egyetért, elfogadja a Társaság alapszabályát, és írásban közli az Elnökséggel belépési szándékát (tagfelvételi kérelem), továbbá, akinek felvételét a Társaság két alapító tagja írásban támogatja. A Társaság körébe várjuk mindazokat, akiket a Társaság céljai és szakmai programja érdekel, és közremúködésükkel segíteni kívánják azok megvalósítását. A Társaságot a tagok adományaira alapozva kívánjuk múködtetni. Az érdeklődők további információt kaphatnak Békés Zoltántól (bekes. zoltan@chello.hu) és Harcsa Istvántól (istvan.harcsa@yahoo.com.)

A Gazsó Ferenc Társadalomtudományi Társaság Elnöksége 